\title{
Correction to: Use of prescribing safety quality improvement reports in UK general practices: a qualitative assessment
}

\author{
Nada F. Khan ${ }^{1 *}$, Helen P. Booth², Puja Myles², David Mullett ${ }^{3}$, Arlene Gallagher ${ }^{2}$, Catheryn Evans²,
}

Nicholas P. B. Thomas ${ }^{3}$ and Janet Valentine ${ }^{2}$

\section{Correction to: BMC Health Serv Res 21, 394 (2021) \\ https://doi.org/10.1186/s12913-021-06417-0}

In the original publication of this article [1], the spelling of the author Nicholas PB Thomas needs to be corrected.

The incorrect author name is: Nick Thomas

The correct author name is: Nicholas PB Thomas

The author group has been updated above, and the original publication has been corrected.

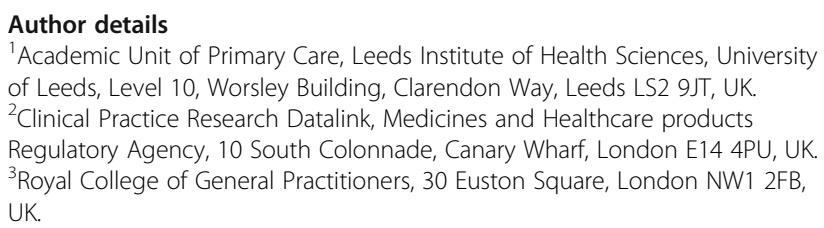

Published online: 02 June 2021

\section{Reference}

1. Khan, et al. Use of prescribing safety quality improvement reports in UK general practices: a qualitative assessment. BMC Health Serv Res. 2021;21:394.

The original article can be found online at https://doi.org/10.1186/s12913021-06417-0.

* Correspondence: nadakhan@nhs.net

${ }^{1}$ Academic Unit of Primary Care, Leeds Institute of Health Sciences, University of Leeds, Level 10, Worsley Building, Clarendon Way, Leeds LS2 9JT, UK

Full list of author information is available at the end of the article

(c) The Author(s). 2021 Open Access This article is licensed under a Creative Commons Attribution 4.0 International License, which permits use, sharing, adaptation, distribution and reproduction in any medium or format, as long as you give appropriate credit to the original author(s) and the source, provide a link to the Creative Commons licence, and indicate if changes were made. The images or other third party material in this article are included in the article's Creative Commons licence, unless indicated otherwise in a credit line to the material. If material is not included in the article's Creative Commons licence and your intended use is not permitted by statutory regulation or exceeds the permitted use, you will need to obtain permission directly from the copyright holder. To view a copy of this licence, visit http://creativecommons.org/licenses/by/4.0/ The Creative Commons Public Domain Dedication waiver (http://creativecommons.org/publicdomain/zero/1.0/) applies to the data made available in this article, unless otherwise stated in a credit line to the data. 